\title{
The Histo-morphometric Evidences of Vernonia amygdalina Leaf Extract-induced Testicular Toxicity
}

\author{
Evidencias Histomorfométricas de la Toxicidad Testicular Inducida \\ por el Extracto de la Hoja de Vernonia amygdalina
}

Saalu, L. C. ; Akunna, G. G.* \& Oyewopo, A. O.**

SAALU, L. C.; AKUNNA, G. G. \& OYEWOPO, A. O. The histomorfometric evidences of Vernonia amygdalina leaf extract-induced testicular toxicity. Int. J. Morphol., 31(2):662-667, 2013.

SUMMARY: Vernonia amygdalina (bitter-leaf) is native to West Africa but occurs mostly in its cultivated form in various parts of central and southern Nigeria. It is a dark-green leafy vegetable commonly used in cooking and as folkloric medicine for the management of several diseases in Nigeria. In the present study, the effects of varying doses of ethanolic leaf extract of Vernonia amygdalina on the rat testis histo-morphometry were investigated. Forty male wistar rats were divided into groups of four. Group A, as the control was given $10 \mathrm{ml} / \mathrm{kg} /$ day/oral distilled water while Group B, C and D subsequently treated with 100, 300 and $600 \mathrm{mg} / \mathrm{kg} / \mathrm{day} / \mathrm{oral} \mathrm{route}$ Vernonia amygdalina leaves extract respectively for 56 days. Results showed that Group B rats had normal testis histology comparable to the control group. However, rats in Group $\mathrm{C}$ and $\mathrm{D}$ exhibited dose-dependent poor testes histo-morphometric profiles, with the higher dosage-group (D) providing a worse feature. Thus, there was a statistically significant $(\mathrm{p}<0.05)$ reduction in the tubular diameter, crosssectional area of the tubules, number of tubular profiles per unit area and the mean numerical density of seminiferous tubules of Group $\mathrm{C}$ and Group D animals compared to the control group. Our results therefore indicated that, while the lower dose (100 mg/kg) of Vernonia amygdalina leaves extract can be accommodated by rat testis, the higher doses (300 mg/ $/ \mathrm{kg}$ and $600 \mathrm{mg} / \mathrm{kg}$ ) demonstrate testicular toxicity in the rat.

KEY WORDS: Vernonia amygdalina; Histology; Morphometry; Testis; Wistar rat.

\section{INTRODUCTION}

It is paramount to be acquainted with the fact that accurate morphometric information may not only provide answers to important questions about the spermatogenic process but may also correlate with physiological and biochemical findings, leading to a complete understanding of infertility.

Globally, infertility affects about 50 to 80 million couples at some point of their reproductive lives with a variety of biological and behavioral determinants (WHO, 2003).

Various medicinal plants ranging from Quassia amara (Raji \& Bolarinwa, 1997), Carica papaya (Lohiya et al., 1994), Ruta graveolens (Khouri \& El-Akawi, 2005), Terminalia catappa (Ratnasooriya \& Dharmasiri, 2000), Ricinus communis (Raji et al., 2006), Garcinia kola (Akpantah et al., 2003) and Vernonia amygdalina (Oyeyimi et al., 2008) have been implicated in male infertility.
Fortunately, several countries in the world are gifted with plant biodiversity, and there is currently an emanating awareness about the significance of plant remedies in health care delivery system. In many parts of the world, efforts are now being aimed at investigating therapeutic efficacy of locally available medicinal herbal plants.

Researching to the efficacy of herbs used in traditional practice would be valuable in establishing standard dosages for herbal preparations and to scrutinize their toxicity (Saalu et al., 2008; Saalu et al., 2010; Akunna et al., 2012). One of such herbs is Vernonia amygdalina.

Vernonia amygdalina, popularly known as "bitter leaf" is a shrub of 2-5 m tall with petiolate leaves of about $6.0 \mathrm{~mm}$ wide. It is widely distributed in Nigeria especially in the south-eastern part of the country. "Bitter leaf" is popular in Nigeria because of its dietary and diverse medicinal uses (Ojiako \& Nwanjo, 2006). It is known as Onugbu in eastern

\footnotetext{
* Department of Anatomy, Lagos State University College of Medicine (LASUCOM), Ikeja, Lagos, Nigeria.

** Department of Anatomy, College of Medicine, University of Ilorin, Ilorin, Nigeria
} 
part of Nigeria were it is renowned for its flavoring ability, as Ewuro in Western part and Chusar Doki in Northern part of Nigeria. The leaf decoction of Vernonia amygdalina is used traditionally in treatment of diabetes, malaria, fever, hiccups, and gastric discomfort (Dalziel, 1937; Bever, 1960). It has been reported to exert schistosomicidal, anti-plasmodial, antitumorigenic and anti-cancer effects (Hamowia \& Saffaf, 1994; Ojiako \& Nwanjo; Oyeyimi et al.).

Phytochemically, Vernonia amygdalina consist of several stigmasranerype saponins, such as vernonioside A, Bl, 42, A3, 82, D3, A.4, and C (Jisaka et al., 1993). Sun dried leaves of Vernonia amygdalina has been reported to contain saponins, tannins, iron, zinc, magnesium, sodium, potassium, caicium and phosphorus (Akindahunsi \& Salawu, 2005).

In 1993, Jisaka et al., reported that the leaves contain vernodaline and vernolide which were evident by elicit antitumoural activity in leukaemia cell P-388 and C 1210. Igile et al., (1994) demonstrated the anti-oxidant activities of luteoiin-o-p-glucosidfela vonoid compounds present in the leaves of Vernonia amygdalina using the united oxidation of $\beta$-carotene linoleic.

Although the use of herbs has more than tripled over the last decade, little scientific support exists to aid in regulation of the dosage of plant extract in folkloric medicine which may be valuable in forestalling a prospective testiculo-toxic effect.

This study consequently investigated the aftermath of different doses of fresh Vernonia amygdalina leaves extract on rat testis histo-morphometry.

\section{MATERIAL AND METHOD}

Procurement of the plant material. The leaves of Vernonia amygdalina were purchased in a local market at Bariga Lagos State, Nigeria. They were authenticated by a staff in the herbarium of the Department of Botany, University of Lagos, Lagos, Lagos state, Nigeria, where a voucher specimen was deposited for reference. The leaves were thoroughly washed in sterile water and the water was then drained from the leaves.

Plant extraction. The leaves of Vernonia amygdalina was dried on a laboratory table for 8 days and reduced to powder. One hundred grams of the powder was macerated in $95 \%$ ethanol $(300 \mathrm{ml})$ for 72 hours. The liquid extract obtained was concentrated in voacuo at $40 \mathrm{oC}$. The yield was $3.77 \%$. The extract was stored in a refrigerator at $4 \mathrm{oC}$ until used.
Experimental etiquette. The protocol of experimentation was approved by the Departmental Ethical Committee responsible for the use of laboratory Animals, Lagos State University. The study is consistent with the standard of the use of laboratory animals (World Medical Association \& American Physiological Society, 2002).

Forty adult male Sprague-Dawley rats (10 to 11 weeks old) weighing 175-180 $\mathrm{g}$ were used for this research work. The rats were randomly divided into four groups (AD) of ten rats each such that the average weight difference between and within groups did not exceed $\pm 20 \%$ of the average weight of the sample population. Rats in group $A$ which served as control were given $10 \mathrm{ml} / \mathrm{kg} /$ day of distilled water for 56 days. Rats in groups B- D served as the treatment groups and were orally treated with 100, 300 and $600 \mathrm{mg} /$ $\mathrm{kg} / \mathrm{day}$ of the extract, respectively, for 56 days, the extent of spermatogenesis in rat being 51.6-56 days (Heller \& Clermont, 1964; Jegou et al., 2002). The appropriate quantity of the ethanolic extract was given orally through an orogastric cannula into the stomach via the esophagus (Prakash, 1981). The extract was administered once daily by 12 noon for six days (Monday to Saturday) within a week.

Animal sacrifice and sample collection. The rats were at the time of sacrifice first weighed and then anaesthetized by placing them in a closed jar containing cotton wool soaked with chloroform anaesthesia. The abdominal cavity was opened up through a midline abdominal incision to expose the reproductive organs. Then the testes were excised and trimmed of all fat. The testes weights of each animal were evaluated.The testes were weighed with an electronic analytical and precision balance (BA 210S, $\mathrm{d}=0.0001$ Sartoriusen GA, Goettingen, Germany). The testes volumes were measured by water displacement method using Archimedes principle (Acott, 1999). The two testes of each rat were measured and the average value obtained for each of the two parameters was regarded as one observation. Testes of each animal were fixed in $10 \%$ formol-saline for histological examination.

Determination of morphometric parameters. Histological slides were prepared from the formol-saline fixed testes. However, before embedding, it was ensured that the sections were orientated perpendicular to their long axes, and chosen as "vertical sections". For each testis, five vertical sections from the polar and the equatorial regions were sampled (Qin \& Lung, 2002) and an unbiased numerical estimation of the following morphometric parameters was estimated using a systematic random scheme (Gundersen \& Jenson, 1987):

Diameter (D) of seminiferous tubules. The diameter of seminiferous tubules with profiles that were round or nearly 
round were estimated for each animal and a mean, D, was determined by taking the average of two diameters, D1 and D2 (Perpendicular to one another). D1 and D2 were taken no more than when D1/D2 $\geq 0.85$.

Cross-sectional area (AC) of the seminiferous tubules. The cross-sectional areas of the seminiferous tubules was estimated from the formula $\mathrm{AC}=\pi \mathrm{D} 2 / 4$ (where $\pi$ is equivalent to 3.142 and $\mathrm{D}$ the mean diameter of the seminiferous tubules).

Number of profiles of seminiferous tubules in a unit area of testis (NA). The Number of profiles of seminiferous tubules per unit area was determined using the unbiased counting frame anticipated by Gundersen (1977). Using this frame, in addition to counting profiles completely inside the frame we counted all profiles with any part inside the frame provided they do not intersect the forbidden line (fulldrawn line) or exclusion edges or their extension.

Numerical Density (NV) of seminiferous tubules. This is the number of profiles per unit volume and was determined by using the modified Floderus equation: $\mathrm{NV}=\mathrm{NA} /(\mathrm{D}+\mathrm{T})$ (Gilliland et al., 2001) where, NA is the number of profiles per unit area, $\mathrm{D}$ is the diameter and $\mathrm{T}$ the average thickness of the section.

The evaluation of the diameter was done with calibrated eyepiece and stage grids mounted on a light research microscope. Estimation of volume density of testicular components and number of seminiferous tubules were done on a computer monitor onto whom a graph sheet was superimposed and on which slides were projected from a research light microscope (Model N-400ME, CEL-TECH Diagnostics, Hamburg, Germany).

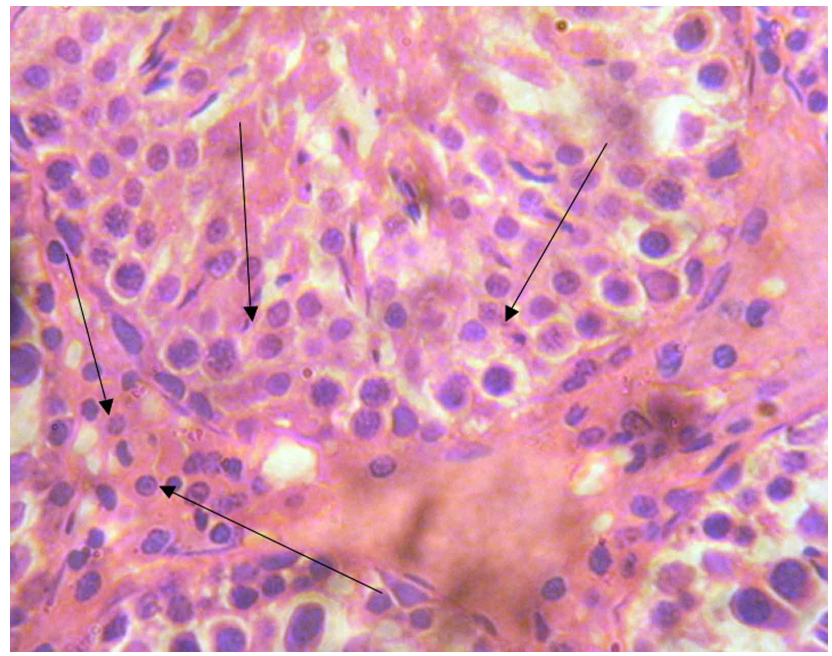

Fig. 1. Photomicrograph of group A rat testes stained with H\&E. X 400 S; seminiferous tubules L; lumen, 1; Leydig cell.
Statistical analysis. The data were statistically analyzed and expressed as Mean \pm SD. Analysis was carried out using analysis of variance (ANOVA) with Scheffe's post hoc test. The level of significance was considered at $\mathrm{p}<0.05$.

\section{RESULTS}

As shown in Figure 2, the group of animals that were administered $100 \mathrm{mg} / \mathrm{kg}$ of the Vernonia amygdalina leaves extract showed normal testis histology comparable to the control group (Fig. 1). However, figures 3 and 4 showed that the group of animals that were given $300 \mathrm{mg} / \mathrm{kg}$ and $600 \mathrm{mg} / \mathrm{kg}$ of the extract respectively exhibited dose-dependent poor testes histo-morphometric profiles, with the higher dosage providing a worse feature as shown in figure 4.

As shown in Table I, the mean seminiferous tubular diameters of rats treated with 300 and $600 \mathrm{mg} / \mathrm{kg}$ were: $113.42 \pm 10.12 \mathrm{~b}$ and $100.21 \pm 7.13 \mathrm{~b} \mathrm{~mm}$ respectively. These values showed a significant decline $(p<0.05)$ compared to the tubular diameter $(160.41 \pm 8.22 \mathrm{~mm})$ of control rats. However, there was a significant increase in the tubular diameter (210.24 $\pm 11.13 \mathrm{a})$ of animals treated with $100 \mathrm{mg} /$ $\mathrm{kg}$ of the extract compared to tubular diameter (160.41 \pm 8.22 $\mathrm{mm}$ ) of the control rats.

The disparity in the cross-sectional area of the tubules, the number of tubular profiles per unit area and the mean numerical density of seminiferous tubules treaded a similar pattern as the tubular diameter (Table I). However, there was a significant increase in the cross-sectional area of the tubules, the number of tubular profiles per unit area and the mean numerical density of seminiferous tubules treated with $100 \mathrm{mg} / \mathrm{kg}$ of the extract (Table I).

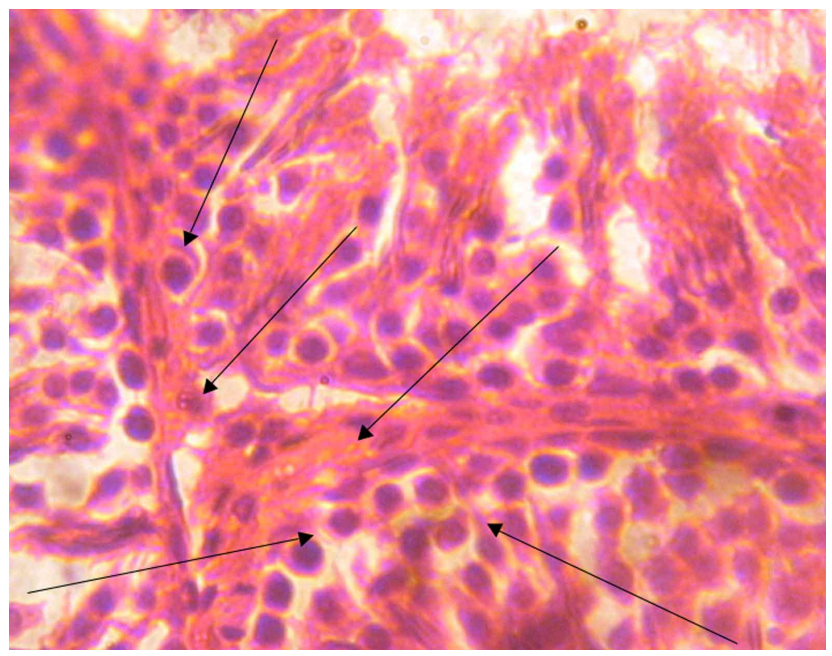

Fig. 2. Photomicrograph of group B rats testes stained with H\&E. X 400 S; seminiferous tubules L;lumen, 1; Leydig cell. 


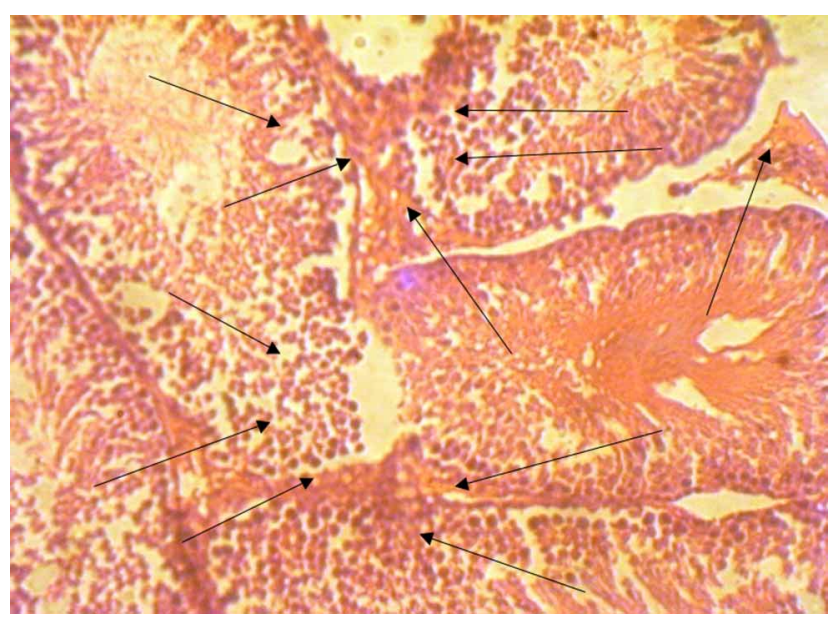

Fig. 3. Photomicrograph of group $\mathrm{C}$ rat testes stained with H\&E. X 400 S; seminiferous tubules L;lumen, 1; Leydig cell

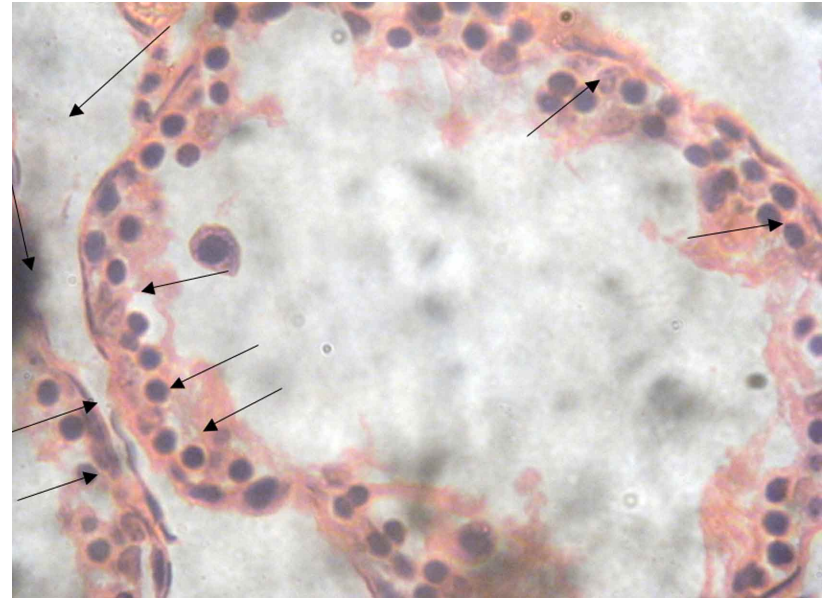

Fig. 4. Photomicrograph of group D rat testes stained with H\&E. X 400 S; seminiferous tubules L;lumen, 1; Leydig cell.

Table I. Seminiferous tubular diameter, cross sectional area, numerical densities of seminiferous tubules and number of profiles per unit area in experimental and control Sprague-Dawley rats.

\begin{tabular}{lllll}
\hline Treatment & \multicolumn{1}{c}{$\mathbf{D}(\mu \mathrm{m})$} & \multicolumn{1}{c}{$\mathbf{A}_{\mathbf{c}}\left(\mathrm{x} 10^{3} \mu \mathrm{m}^{2}\right)$} & $\mathbf{N}_{\mathbf{A}}\left(\mathrm{X} 10^{-8} \mu_{\mathrm{m}^{-2}}\right)$ & $\mathbf{N}_{\mathbf{v}}\left(\mathrm{x} 10-10 \mu \mathrm{m}^{-3}\right)$ \\
\hline A & $160.41 \pm 8.22$ & $27.51 \pm 8.13$ & $24.21 \pm 5.13$ & $11.13 \pm 4.75$ \\
B & $210.24 \pm 11.13 \mathrm{a}$ & $43.54 \pm 5.12 \mathrm{a}$ & $33.52 \pm 4.12 \mathrm{a}$ & $19.53 \pm 4.23 \mathrm{a}$ \\
C & $113.42 \pm 10.12 \mathrm{~b}$ & $18.40 \pm 6.24 \mathrm{~b}$ & $14.45 \pm 3.33 \mathrm{~b}$ & $7.63 \pm 5.57 \mathrm{~b}$ \\
D & $100.21 \pm 7.13 \mathrm{~b}$ & $15.35 \pm 1.12 \mathrm{~b}$ & $11.42 \pm 1.43 \mathrm{~b}$ & $5.13 \pm 3.82 \mathrm{~b}$ \\
\hline
\end{tabular}

$\mathrm{a}, \mathrm{b}$ represent significant increase and decrease respectively at $\mathrm{P}<0.05$ when compared to control values. All values are expressed as Mean \pm Standard deviation $(\mathrm{n}=10) . \mathrm{A}=10 \mathrm{ml} / \mathrm{kg} /$ day/oral distilled water (Control), $\mathrm{B}=100 \mathrm{mg} / \mathrm{kg} /$ day $/$ oral $V A$ extract, $\mathrm{C}=300 \mathrm{mg} / \mathrm{kg} /$ day $/$ oral $V A$ extract, $\mathrm{D}=600 \mathrm{mg} / \mathrm{kg} /$ day $/$ oral $V A$ extract.

\section{DISCUSSION}

Describing histological sections with stereological methods helps to unravel some essential issues allied with qualitative microscopic investigation.

In this study, analysis was carried out on randomly sampled vertical histological sections using stereological method in a bid to uphold accuracy in favor of the investigation.

The results showed a dose dependent significant $(\mathrm{P}<0.05)$ decrease in the mean seminiferous tubular diameters, cross-sectional area of the tubules, number of tubular profiles per unit area and the mean numerical density of seminiferous tubules of rats treated with 300 and $600 \mathrm{mg} /$ $\mathrm{kg}$ of Vernonia amygdalina leaf extract. The significant reduction in these geometric values was supported by the distortion in the morphological features of the seminiferous epithelium and interstitium (Figs. 3 and 4), which is liable for the outstanding production of the luminal fluid (Okanlawon \& Ashiru, 1998).
Avalanche of studies have reported the important roles played by germinal epithelium in production of luminal fluid which is a precursor for spermatogenesis (Fisher, 2002; Syed \& Hecht, 2002). The leydig cell determines the size of the interstitium thus several reports (Castro et al., 2002; Saalu et al., 2011) correlates the level of testicular testosterone with the number of Leydig cell. The reduction in morphometric values coupled with the degenerated epithelium in the present study only bolstered previous report (Fisher, 2002; Castro et al., 2002, Saalu et al., 2011). In 2008, Oyeyemi et al., reported a significant reduction in sperm count, sperm motility, percentage of normal sperm and an increase in the percentage of abnormal sperm postadministration of 250 and $500 \mathrm{mg} / \mathrm{kg} / \mathrm{body}$ weight of aqueous extract of Vernonia amygdalina. The dose-reliant decline in the testicular volume and diameter of the tubules from our study would only imply a significant decline in the interstitium due to the destruction of the Leydig cells. This suggests that the extract affected the process of spermatogenesis as reflected by a dwindle in the mean 
seminiferous tubular diameters, cross-sectional area of the tubules, number of tubular profiles per unit area and the mean numerical density of seminiferous tubules of rats treated with 300 and $600 \mathrm{mg} / \mathrm{kg}$ of Vernonia amygdalina leaf extract.

However, the group of animals that were treated with $100 \mathrm{mg} / \mathrm{kg}$ of the Vernonia amygdalina leaves extracts showed normal histo-morphometric profiles comparable to the control group (Fig. 1). The report indicated that lower dose $(100 \mathrm{mg} / \mathrm{kg})$ of Vernonia amygdalina leaves extracts had no deleterious effect on the testis. This result is in conformity with several reports (Ohigashi et al., 1991; Jisaka et al.; Igile et al.; Oyeyemi et al.).

Three dimensional deductions obtained from the present study provide quantitative evidence that the ethanolic leaf extract of Vernonia amygdalina is testiculotoxic at 300 $\mathrm{mg} / \mathrm{kg}$ and $600 \mathrm{mg} / \mathrm{kg}$ of dosage. Due to the quantity of spermatogenic cells in the basal layer and the Sertoli-Sertoli cell barrier which determines the number of cells in the adluminal compartment (Osinubi, 2006); we would be unable to conclude based on the histo-morphometric alterations in the present study. Nevertheless, the three-dimensional evaluations obtained in this study are a sound conclusion of the histo-morphometric characteristic of the rat testis.

The results of this study therefore indicate that, while the lower dose $(100 \mathrm{mg} / \mathrm{kg})$ of Vernonia amygdalina leaves extract had no harmful effect on the rat testis; the higher doses $(300 \mathrm{mg} / \mathrm{kg}$ and $600 \mathrm{mg} / \mathrm{kg})$ indeed demonstrate testicular toxicity in the rat.

CONCLUSION. A regulation of the dosage of this extract in folkloric medicine may therefore be beneficial in forestalling a possible reproductive impairment. This is even more significant when one considers that the vulnerability of man to toxic substances would be higher than that of rodents since rodents posses more efficient xenobiotic biotransformation system than man (Lüllmann et. al., 1973).

SAALU, L. C.; AKUNNA, G. G. \& OYEWOPO, A. O. Evidencias histomorfométricas de la toxicidad testicular inducida por el extracto de la hoja de Vernonia amygdalina. Int. J. Morphol., 31(2):662-667, 2013.

RESUMEN: La Vernonia amygdalina (hoja amarga) es originaria de África Occidental, pero se produce mediante cultivo en varias partes del Centro y Sur de Nigeria. Es una verdura, una hoja color verde oscuro, común en la cocina y como medicina alternativa en el manejo de varias enfermedades en Nigeria. Se investigaron los efectos de diferentes dosis de extracto etanólico de la hoja de Vernonia amygdalina para estudiar los efectos sobre la histomorfometría testicular en la rata. Cuarenta ratas Wistar macho se dividieron en 4 grupos. Grupo A, como control con el suministro de $10 \mathrm{ml} / \mathrm{kg} /$ día/agua destilada vía oral, y los Grupos $\mathrm{B}, \mathrm{C}$ y D tratados con 100, 300 y $600 \mathrm{mg} / \mathrm{kg} /$ día/ vía oral del extracto de Vernonia amygdalina, durante 56 días. Los resultados mostraron que las ratas del grupo B tenían una histología testicular normal y comparable con el grupo control. Sin embargo, las ratas del grupo C y D mostraron bajos perfiles histomorfométricos testiculares, dependientes de la dosis, y con la dosis más elevada, grupo (D) se observaron característica aún menores. Hubo una reducción estadísticamente significativa $(\mathrm{p}<0,05)$ en el diámetro tubular, área de sección transversal de los túbulos, número túbulos por unidad de superficie y densidad numérica media de los túbulos seminíferos del Grupo C y D en comparación con el grupo de control. Nuestros resultados indicaron que dosis bajas $(100 \mathrm{mg} / \mathrm{kg})$ del extracto de Vernonia amygdalina pueden ser aceptables y no alteran el testículo de rata, pero con dosis altas $(300 \mathrm{mg} / \mathrm{kg}$ y $600 \mathrm{mg} / \mathrm{kg}$ ) se observa toxicidad testicular.

PALABRAS CLAVE: Vernonia amygdalina; Histología; Morfometría; Testículo; Rata Wistar.

\section{REFERENCES}

Acott, C. The diving "Law-ers": A brief resume of their lives. South Pacific Underwater Med. Soc. J., 29(1):39-42, 1999.

Akindahunsi, A. \& Salawu, S. O. Phytochemical screening and nutrientantinutrient composition of selected tropical green leafy vegetables. Afr. J. Biotechnol., 4(6):497-501, 2005.

Akpantah, A. O.; Oremosu, A. A.; Ajala, M.; Noronha, C. C. \& Okanlawon, C. C. The effect of crude extract of garcina kola seed on the histology and hormonal milieu of male Sprague Dawley rats' reproductive organs. Nig. J. Health Biomed. Sci., 2(1):40-6, 2003.

Akunna, G. G.; Saalu, C. L.; Ogunmodede, O. S.; Ogunlade, B.; Be1lo, A. J. \& Salawu, E. O. Ameliorative Effect of Moringa oleifera (drumstick) Leaf Extracts on Chromium-Induced Testicular Toxicity in Rat Testes. World J. Life Sci. Med. Res., 2:20-6, 2012.

Bever, B. O. Medicinal Plants in Nigeria. Ibadan, College of Arts, Science and Technology, 1960. p.17.

Castro, A. C.; Berndtson, W. E. \& Cardoso, F. M. Plasma and testicular testosterone level, $\mathrm{Vv}$ and number of Leydig cells and spermatogenic efficiency of rabbits. Braz. J. Med. Biol. Res., 35(4):493-8, 2002.

Dalziel, J. M. The Useful Plants of West Tropical Africa. London, Crown Overseas Agents for the Colonies, 1937. p.65.

Fisher, D. New light shed on fluid formation in seminiferous tubules of the rat. J. Physiol., 542(Pt 2):445-52, 2002.

Gilliland, K. O.; Freel, C. D.; Lane, C. W.; Fowler, W. C. \& Costello, N. J. Multilamellar bodies as potential scattering particles in human age-related nuclear cataracts. Mol. Vis., 7:120-30, 2001. 
Gundersen, H. J. G. \& Jensen, E. B. The efficiency of systematic sampling in stereology and its predictions. J. Microsc., 147(Pt 3):229-63, 1987.

Gundersen, H. J. G. Notes on the estimation of the numerical density of arbitrary profiles: The edge effect. J. Microsc., 111(2):219-23, 1977.

Hamowia, A. M. \& Saffaf, A. M. Pharmacological studies on Vernonia amygdalina (Del) and Tithonia diversifolia (Gray). Vet. Med. J. Giza, 42(2):91-7, 1994.

Heller, C. G. \& Clermont, Y. Spermatogenesis in man: An estimate of its duration. Science, 140(3563):184-6, 1963.

Igile, G. O.; Oleszek, W.; Jurzyata, M.; Burda, S.; Fafunso, M. \& Fasonmade, A. A. Flavoids from Vernonia amygdalina and their antioxidant activities. J. Agric. Food Chem., 42(11):2445-8, 1994.

Jegou, B.; Pineau, C. \& Toppari, J. Spermatogenesis in vitro in mammals. In: de Jonge, C. J. \& Barratt, C. L. R. (Eds.). Assisted Reproductive Technology: Accomplishments and New Horizons. Cambridge, Cambridge University Press, 2002. pp.3-60.

Jisaka, M.; Ohigashi, H.; Takagawa, K.; Nozaki, H.; Hirota, M.; Irie, R.; Huffman, M. A.; et al. Steroid glycosides from Vernonia amygdalina. A possible chimpanzee medicinal plant. Phytochemistry, 34(2):409-13, 1993.

Khouri, N. A. \& El-Akawi, Z. Antiandrogenic activity of Ruta graveolens $\mathrm{L}$ in male Albino rats with emphasis on sexual and aggressive behavior. Neuro. Endocrinol. Lett., 26(6):823-9, 2005.

Lohiya, N. K.; Goyal, P. B.; Jayaprakash, D.; Ansari, A. S. \& Sharma, S. Antifertility effects of aqueous extract of Carica papaya seeds in male rats. Planta Med., 60(5):400-4, 1994.

Lüllmann, H.; Lüllmann-Rauch, R. \& Wassermann, O. Drug-induced phospholipidosis. Ger. Med., 3(3-4):128-35, 1973.

Ohigashi, H.; Jisaka, M.; Huffman, M. A. \& Koshimizu, K. Butter principle and a related steroid glucoside from. Vernonia amygdalina - a possible medicinal plant for wild chimpanzee. Agric. Biol. Chem., 55:1201-3, 1991.

Ojiako, O. A. \& Nwanjo, H. U. Is Vernonia amygdalina hepatotoxic or hepatoprotective? Response from biochemical and toxicity studies in rats. Afr. J. Biotechnol., 5(18):1648-51, 2006.

Okanlawon, A. O. \& Ashiru, O. A. Sterological estimation of seminiferous tubular dysfunction in chloroquine treated rats. Afr. J. Med. Med. Sci., 27(1-2):101-6, 1998.

Osinubi, A. A. Quinine-induced cytoarchitectural and morphometric alterations in the testes of Sprague-Dawley rats. Ph.D. Thesis, Lagos, University of Lagos, 2006.

Oyeyimi, M. O.; Oluwatoyin, O.; Ajala Leigh, O. O. \& Adesiji, T. F. The spermiogram of Wistar rats treated with aqueous leaf extract of Vernonia amygdalina. Folia Vet., 52(2):98-101, 2008.

Prakash, O. Antifertility investigations on embelin -- an oral contraceptive of plant origin. Part I -- Biological properties. Planta Med., 41(3):259-66, 1981.
Qin, D. N. \& Lung, M. A. Morphometric study on leydig cells in capsulotomized testis of rats. Asian J. Androl., 4(1):49-53, 2002.

Raji, Y. \& Bolarinwa, A. F. Antifertility activity of Quassia amara in male rats-in vivo study. Life Sci., 61(11):1067-74, 1997.

Raji, Y.; Oloyo, A. K. \& Morakinyo, A. O. Effect of methanol extract of Ricinus communis seed on reproduction of male rats. Asian J. Androl., 8(1):115-21, 2006.

Ratnasooriya, W. D. \& Dharmasiri, M. G. Effects of Terminalia catappa seeds on sexual behaviour and fertility of male rats. Asian J. Androl., 2(3):213-9, 2000

Saalu, L. C.; Kpela, T.; Benebo, A. S.; Oyewopo, A. O.; Anifowope, E. O. \& Oguntola, J. A. The Dose-Dependent Testiculoprotective and Testiculotoxic Potentials of Telfairia occidentalis Hook f. Leaves Extract in Rat. Int. J. of Applied Research in Natural Products, $3(3): 27-38,2010$

Saalu, L. C.; Osinubi, A. A.; Akinbami, A. A.; Yama, O. E.; Oyewopo, A. O. \& Enaibe, B. U. Moringa oleifera Lamarck (drumstick) Leaf Extract Modulates the Evidences of Hydroxyurea -Induced Testicular Derangement. Int. J. of Applied Research in Natural Products, 4(2):32-45, 2011.

Saalu, L. C.; Udeh, R.; Oluyemi, K. A.; Jewo, P. I. \& Fadeyibi, L. O. The Ameliorating effects of Grapefruit seed extract on testicular morphology and function of varicocelized rats. Int. J. Morphol., 26(4):1059-64, 2008

Syed, V. \& Hecht, N. B. Disruption of germ cell-Sertoli cell interactions leads to spermatogenic defects. Mol. Cell Endocrinol., 186(2):1557, 2002.

World Health Organisation (WHO). Laboratory manual for examination of human semen. $4^{\text {th }}$ ed. Cambridge, Cambridge University Press, 2003.

World Medical Association \& American Physiological Society. Guiding principles for research involving animals and human beings. Am. J. Physiol. Regul. Integr. Comp. Physiol., 283(2):R281-3, 2002.

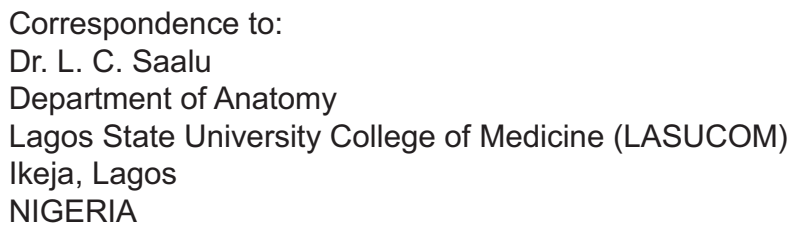

Tel. No: +2348033200876

Email: drchiasaalu@yahoo.com

Received: 08-08-2012

Accepted: 04-01-2013 